\title{
Comparison of Cytocompatibility and Anticancer Properties of Traditional and Green Chemistry-Synthesized Tellurium Nanowires [Corrigendum]
}

\author{
Vernet Crua A, Medina D, Zhang B, et al. The authors wish to apologize for this error and advise that \\ Int J Nanomedicine. 2019;14:3155-3176. \\ this does not change the conclusions of the paper.
}

The authors have advised they inadvertently published the wrong image for Figure 11 on page 3166. The correct Figure 11 is as follows.
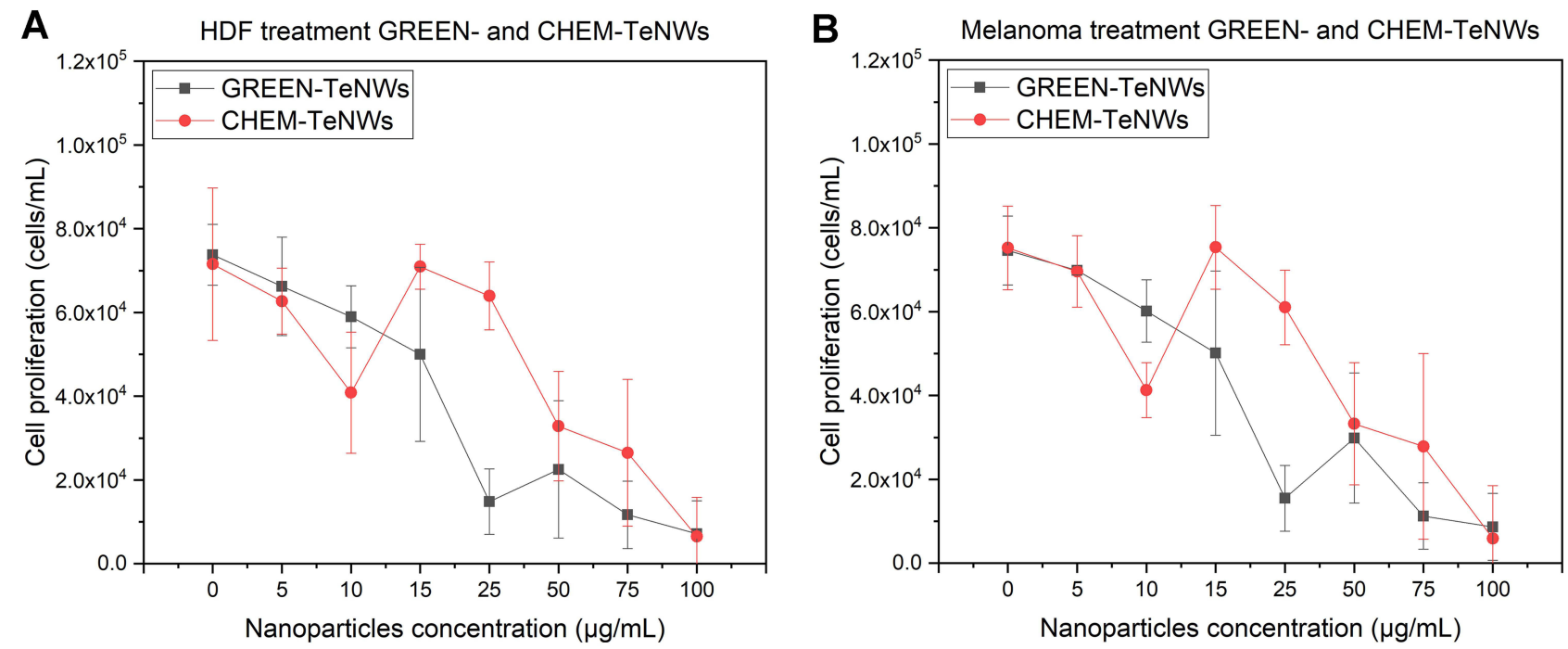

Figure I I Comparison between CHEM-TeNWs and GREEN-TeNWs for HDF (A) and melanoma (B) cells at the fifth day of experiment. Data from MTS assays on HDF and melanoma cells in the presence of TeNWs.

Abbreviations: CHEM-TeNWs, chemically synthesized TeNWs; GREEN-TeNWs, green-synthesized TeNWs; HDF, human dermal fibroblasts; TeNWs, tellurium nanowires.

International Journal of Nanomedicine

Dovepress

\section{Publish your work in this journal}

The International Journal of Nanomedicine is an international, peerreviewed journal focusing on the application of nanotechnology in diagnostics, therapeutics, and drug delivery systems throughout the biomedical field. This journal is indexed on PubMed Central, MedLine, CAS, SciSearch ${ }^{\mathbb{B}}$, Current Contents ${ }^{\mathbb{R}} /$ Clinical Medicine,
Journal Citation Reports/Science Edition, EMBase, Scopus and the Elsevier Bibliographic databases. The manuscript management system is completely online and includes a very quick and fair peer-review system, which is all easy to use. Visit http://www.dovepress.com/ testimonials.php to read real quotes from published authors. 